\title{
CALENDAR OF COMPUTER-GAMES EVENTS 1994
}

\section{September 29 - October 3}

The $4^{\text {th }}$ International Paderborn Computer-Chess Championship, to be held at the University of Paderborn, Germany.

Details from Ulf Lorenz and Valentin Rottmann, Fachbereich 17 Informatik, University of Paderborn, D-33095 Paderborn, Germany; Email: johta2@uni-paderborn.de.

\section{October 1 - 2}

The $5^{\text {th }}$ Harvard Cup Human versus Computer Chess Challenge, to be held at The Computer Museum, Boston, MA, USA.

Details from Christopher Chabris, P.O. Box 2967, Harvard Square Station, Cambridge, MA 02238 USA. Telephone: +1-617-876-5759; fax: +1-617-491-9570; Email: cfc@isr.harvard.edu.

\section{October $15-16 / 22-23$}

The $14^{\text {th }}$ Dutch Computer Chess Championship, to be held in Leiden, The Netherlands.

Details: Theo van der Storm, Wethouder Driessenstraat 5, 1107 XG Amsterdam ZO, The Netherlands.

Telephone: +31-20-6913044.

\section{THE 1995 WORLD COMPUTER-CHESS CHAMPIONSHIP Preliminary Announcement}

\author{
D.N.L. Levy ${ }^{1}$
}

London, England

The ICCA is in discussion with a potential sponsor about the possibility of holding the $8^{\text {th }}$ World Computer Chess Championship in Hong Kong during the first week of April 1995. At the time of going to press we regret that it is not possible to give any definite information, hence this preliminary announcement.

If the event does take place in Hong Kong the ICCA expects to be able to provide travel and hotel grants for up to 16 non-commercial teams. The total number of entries allowed will probably be up to 24 . The tournament committee would comprise: Professor Tony Marsland, Professor Monty Newborn and David Levy.

In order to allow sufficient time for the ICCA to select the participants and for everyone to make their travel arrangements, the closing date for entries will be December $31^{\text {st }}, 1994$. This may be before publication of the next issue of the ICCA Journal and so it is essential that anyone who might be interested in competing in the World Championship registers their interest as soon as possible. Prospective entrants should write or fax to David Levy with the following information:

- $\quad$ Name of program.

- Name, address, telephone numbers (home and work), fax number and e-mail address of the team member who will be the contact with the ICCA.

If a definite decision is made about the venue and dates of the $8^{\text {th }}$ World Championship before publication of the next issue of the ICCA Journal, everyone who has registered their interest in the event will be notified immediately and provided with full information about the tournament.

\footnotetext{
1 89, Constantine Road, London, NW3 2LP England. Email: DavidL@intrsrch.demon.co.uk. Fax: (+44) 714820672.
} 